\title{
Response of Sweet Corn Hybrid to Transplanting Dates and Nitrogen Levels under Temperate Conditions
}

\author{
Abrar A. Khan ${ }^{1}$, Ashaq Hussain ${ }^{1 *}$, Manzoor ${ }^{1}$, A. Ganai ${ }^{2}$, \\ Zahida Rashid ${ }^{3}$ and Zahoor A. Dar ${ }^{2}$ \\ ${ }^{1}$ Division of Agronomy, Faculty of Agriculture (SKUAST-K), Wadura, \\ Sopore (J\&K), 192 201, India \\ ${ }^{2}$ Mountain Research Centre for Field Crop (SKUAST-K), Khudwani, \\ Anantnag, (J\&K), 192 102, India \\ ${ }^{3}$ Dryland Agricultural Research Station (SKUAST-K), Budgam (J\&K), 190019, India \\ *Corresponding author
}

\section{A B S T R A C T}

A field experiment on "Response of Sweet corn hybrid to transplanting dates and nitrogen

\section{Keywords}

Sweet corn hybrid, Nitrogen levels, Temperate

Article Info

Accepted:

10 March 2018

Available Online:

10 April 2018 levels under temperate conditions" was conducted at research farm of Faculty of Agriculture (SKUAST-K) during 2016. The soil of the experimental field was silty clay loam in texture, low in soil available $\mathrm{N}$ and $\mathrm{P}$ and medium in available $\mathrm{K}$ and neutral in reaction. The treatments comprised of two transplanting dates viz., $1^{\text {st }}$ of May and $1^{\text {st }}$ of June and five levels of $\mathrm{N}$ viz., 0, 30,60, 90 and $120 \mathrm{~kg} / \mathrm{ha}$. Although latter date of sowing resulted in better quality of seedlings but $1^{\text {st }}$ May transplanting was superior in all growth and yield attributes. $1^{\text {st }}$ May transplanting resulted $35.4 \%$ and $19.8 \%$ higher cob yield and green fodder yield over $1^{\text {st }}$ June transplanting, respectively. Nitrogen application resulted in a significant increase in growth and yield parameters. The green cob yield increased by $34 \%, 44 \%, 52 \%$, and $54 \%$ respectively at $30,60,90$ and $120 \mathrm{~kg} / \mathrm{ha} \mathrm{N}$ over control. The corresponding figures for the green fodder yield were $39 \%, 70 \%$, $91 \%$ and $108 \%$, respectively. Highest net profit and benefit cost ratio was realised in $1^{\text {st }}$ May transplanting applied with $120 \mathrm{~kg} \mathrm{~N} / \mathrm{ha}$.

\section{Introduction}

The popularity of sweet corn is fast growing across India due to its sweet taste and high nutritional quality. Its consumption at immature stage as roasted and boiled ears is a popular practice as the kernels are sweet, creamy, tender, crispy and almost shell-less. The awareness about sweet corn in Kashmir valley is also growing gradually and may increase further with the growth in tourism industry. Abundant sunshine, moderate temperature and nearly pest free environment of Kashmir valley is suited for high quality and yield of sweet corn. Optimum sowing/transplanting dates is important to maximize the yield and also to sustain the supplies for a longer time keeping in view the perishable nature of the crop. Planting date is a major factor affecting the sweet corn 
production in addition to other factors such as soil fertility, temperature regimes and irrigation (Ramankutty et al., 2002; Anapalli et al., 2005). Early sowing of sweet corn in first week of April exposes the crop to cold and cut worm damage. The crop can be grown by raising the seedlings under protected conditions and then established using transplanting method. Therefore it was imperative to study the effect of sowing dates on growth and quality seedlings. Earlier planting of corn is preferable because of utilization of the entire growing season, achieving physiological maturity before frost, thereby increasing profit (Lauer et al., 1997) while delays in sowing date reduced individual kernel weight (Cirilo and Andrade, 1996). Among the inputs nitrogen is most critical due to is profound impact on vegetative and reproductive growth of the sweet corn. Nitrogen plays an important role in synthesis of chlorophyll, amino acids and other organic compounds of physiological significance in plant system (Havlin et al., 2005). Therefore a field investigation on the transplanting dates and nitrogen levels was conducted to evaluate the seedling quality and optimize the transplanting dates and $\mathrm{N}$ levels for higher growth and yield and profitability of sweet corn.

\section{Materials and Methods}

A field experiment was conducted at Faculty of Agriculture, Wadura, Sopore to investigate the response of sweet corn to dates of transplanting and nitrogen levels on the yield and quality of sweet corn. It is located at latitude of $34^{\circ} 34^{\prime} \mathrm{N}$, longitude $74^{\circ} 40^{\prime} \mathrm{E}$ and altitude of $1590 \mathrm{~m}$ amsl. The soil of the experimental field was silty clay loam in texture, neutral in reaction, low in available $\mathrm{N}$ $(210 \mathrm{~kg} / \mathrm{ha})$ and $\mathrm{P}(12.3 \mathrm{~kg} / \mathrm{ha})$ and medium in available K (183.5kg/ha). Treatments comprised of two transplanting dates $\left(1^{\text {st }}\right.$ May and $1^{\text {st }}$ June) and five nitrogen levels $(0,30$,
$60,90,120 \mathrm{~kg} / \mathrm{ha}$ ) laid out in RCBD with three replications. The $\mathrm{P}_{2} \mathrm{O}_{5}$ and $\mathrm{K}_{2} \mathrm{O}$ were applied basally@60 and 30 kg/ha. Sweet corn variety Sugar-75 of Syngenta was used as the test variety. The seeds were sown in greenhouse on $10^{\text {th }}$ April and $10^{\text {th }}$ May respectively and transplanted at an age of 20 days. Seedlings were raised under protected in poly bags using poting mixture of $400 \mathrm{~g}$ of soil: sand: manure in the ratio of $2: 1: 1$. The poly bags were teared at the time of transplanting without disturbing the soil. The crop was irrigated four times each at critical stage of the crop. A spacing of $60 \mathrm{~cm} \times 20 \mathrm{~cm}$ was used i.e., a population of 83000 plants /ha. Recommended of dose $60 \mathrm{~kg} / \mathrm{ha} \mathrm{P}_{2} \mathrm{O}_{5}$ and 40 $\mathrm{kg} / \mathrm{ha} \mathrm{K}_{2} \mathrm{O}$ was applied as basal application.

Germination percentage and seedling vigour was calculated as per the following formulae;

Germination percentage $=$

Total no of Seeds Germinated

Total no of Seeds Sown

\section{$\mathrm{x} 100$}

\section{Seedling vigour index I}

Vigour index $\mathrm{I}=$ Germination $\% \times$ Seedling length

\section{Seedling vigour index II}

Vigour index II $=$ Germination $\% \times$ Seedling dry weight (Abdulbaki and Anderson, 1973).

\section{Calculation of economically optimum $\mathrm{N}$ dose}

The production function was used to estimate the optimum dose of nitrogen that gives the maximum profit. The mathematical computation in arriving the optimum dose was as follows

$\mathrm{Y}=\mathrm{a}+\mathrm{bx}+\mathrm{cx^{2 }}$ 


$$
\begin{array}{r}
\mathrm{dy} / \mathrm{dx}=\begin{array}{c}
\mathrm{b}+2 \mathrm{cx} \\
\mathrm{p} / \mathrm{q}-\mathrm{b}
\end{array} \\
\mathrm{X}_{\mathrm{opt}}=-\frac{-\mathrm{cc}}{2 \mathrm{c}}
\end{array}
$$

Where,

$X_{\text {opt }}=$ optimum level of $\mathrm{N} \mathrm{kg} / \mathrm{ha}$

$\mathrm{p}=$ price of $\mathrm{N} ₹ / \mathrm{kg}$

$\mathrm{q}=$ price of green cobs $₹ / \mathrm{kg}$

$\mathrm{a}, \mathrm{b}$ and $\mathrm{c}$ represent regression quotients

\section{Results and Discussion}

\section{Seedling quality parameters}

All the seedling parameters viz., seedling shoot length, seedling root length, seedling fresh and dry weight, germination percentage, no of leaves, seedling vigour index I and II were found to be significantly superior in $10^{\text {th }}$ May sown seedlings (Table 1). Temperature during germination is very important factor as it affects germination and emergence. Therefore, it is fundamental to determine the optimum temperature for the plant. Higher temperature was maintained in the poly-house for $10^{\text {th }}$ May sowing that resulted in high growth rate of the seedlings and thus higher values of various seedling parameters were obtained. Inglett (1970) and Bunting (1971) reported that most maize seed germinated slowly below $10^{\circ} \mathrm{C}$ and germination increases drastically in the higher temperature regimes. Higher rate of growth resulted in taller seedlings with higher dry matter accumulation that resulted in higher seedling vigour for $10^{\text {th }}$ May sowing. Coleptile length and germination rate were affected by different temperatures (Idikut, 2013). Our findings are in agreement with Bockstaller and Girardin (1994), Peterson et al., (1995) and Varga et al., (2012).

\section{Growth attributes}

The data pertaining to the growth parameters viz. plant height, dry matter production, leaf area index, no of functional leaves viz. were observed to be significantly higher in $1^{\text {st }}$ May of transplanting over the $1^{\text {st }}$ June transplanting (Table 2). The plant height, leaf area index, dry matter accumulation and no of functional leaves increased significantly with increase in $\mathrm{N}$ levels (Table 2). The significant decrease in growth parameters following the delay in transplanting can be associated with higher temperatures that the plants in $1^{\text {st }}$ June transplanting limiting their growth period and assimilate building because of early maturity of plants (Moosavi et al., 2012).

Significant effect on the increase on the growth parameters in sweet corn with the application of $\mathrm{N}$ may be attributed to the fact that nitrogen being an essential constituent of plant tissue favours rapid cell division and its enlargement, which together with the adequate quantity of phosphorus and potassium helps in the development of the cell size and vegetative growth. Similar results were also obtained by Mullins et al., (1999), Bindhani et al., (2008), Paradar (2005).

\section{Yield attributes and yield}

Yield viz. number of number of grains/cob, cobs/plant, cob length and cob girth was significantly higher in $1^{\text {st }}$ May transplanting the $1^{\text {st }}$ June transplanting. Earlier transplanting experienced a favourable climate commensurate with various phonological stages of the crop which resulted in superior yield attributes. Similarly green cob yield, green fodder yield and harvest index) were observed to be significantly higher in $1^{\text {st }}$ May transplanting. The cob yield and green fodder yield of $1^{\text {st }}$ May transplanting was $35.4 \%$ and $19.8 \%$ higher over the $1^{\text {st }}$ June transplanting respectively (Table 3). Superior growth and yield attributes in $1^{\text {st }}$ May transplanting was manifested in higher yield. Yield parameters also increased significantly with increasing $\mathrm{N}$ doses. 
Table.1 Effect of sowing dates on different parameters of seedlings of sweet corn

\begin{tabular}{|c|c|c|c|c|c|c|c|c|}
\hline $\begin{array}{l}\text { Sowing } \\
\text { dates }\end{array}$ & $\begin{array}{l}\text { Shoot } \\
\text { length } \\
(\mathrm{cm})\end{array}$ & $\begin{array}{c}\text { Root } \\
\text { length } \\
(\mathrm{cm})\end{array}$ & $\begin{array}{c}\text { Fresh } \\
\text { weight } \\
\text { (g) }\end{array}$ & $\begin{array}{c}\text { Dry } \\
\text { weight } \\
\text { (g) }\end{array}$ & $\begin{array}{l}\text { No. of } \\
\text { leaves }\end{array}$ & $\begin{array}{c}\text { Germination } \\
(\%)\end{array}$ & $\begin{array}{c}\text { Vigour } \\
\text { index- } \\
\text { I }\end{array}$ & $\begin{array}{c}\text { Vigour } \\
\text { index- } \\
\text { II }\end{array}$ \\
\hline $10^{\text {th }}$ April & 19.98 & 12.26 & 4.21 & 1.32 & 3.60 & 93.80 & 3,024 & 123.3 \\
\hline $10^{\text {th }}$ May & 23.12 & 15.54 & 5.27 & 1.74 & 4.80 & 96.00 & 3,716 . & 167.4 \\
\hline SEM \pm & 1.04 & 0.79 & 0.31 & 0.10 & 0.36 & 0.47 & 165.0 & 8.64 \\
\hline $\mathrm{CD}(\mathrm{p} \leq 0.05)$ & 3.09 & 3.19 & 0.98 & 0.33 & 1.08 & 1.89 & 495.0 & 25.92 \\
\hline
\end{tabular}

Table.2 Effect of dates of transplanting and nitrogen levels on growth parameters of sweet corn

\begin{tabular}{|c|c|c|c|c|}
\hline Treatments & $\begin{array}{l}\text { Plant height } \\
\text { (cm) }\end{array}$ & $\begin{array}{l}\text { Leaf area } \\
\text { index }\end{array}$ & $\begin{array}{c}\text { No. of functional } \\
\text { leaves }\end{array}$ & $\begin{array}{c}\text { Dry matter } \\
\text { accumulation } \\
(\mathrm{t} / \mathrm{ha})\end{array}$ \\
\hline \multicolumn{5}{|c|}{ Transplanting dates } \\
\hline $1^{\text {st }}$ May & 275.1 & 5.93 & 11.26 & 120.8 \\
\hline $1^{\text {st }}$ June & 227.6 & 5.28 & 10.10 & 107.9 \\
\hline SEM+ & 0.37 & 0.008 & 0.04 & 0.46 \\
\hline$C D(p \leq 0.05)$ & 1.11 & 0.025 & 0.13 & 1.39 \\
\hline \multicolumn{5}{|c|}{ Nitrogen levels (kg/ha) } \\
\hline 0 & 231.5 & 5.19 & 9.55 & 81.6 \\
\hline 30 & 242.1 & 5.45 & 10.28 & 111.0 \\
\hline 60 & 250.2 & 5.61 & 10.73 & 118.6 \\
\hline 90 & 258.7 & 5.76 & 11.08 & 126.0 \\
\hline 120 & 274.2 & 6.04 & 12.10 & 134.6 \\
\hline SEM \pm & 0.59 & 0.013 & 0.07 & 0.73 \\
\hline$C D(p \leq 0.05)$ & 1.76 & 0.039 & 0.21 & 2.20 \\
\hline
\end{tabular}

Table.4 Effect of dates of transplanting and nitrogen levels on green cob yield t/ha (without husk) of sweet corn

\begin{tabular}{|l|c|c|c|c|c|c|}
\hline & $\mathbf{N}_{0}$ & $\mathbf{N}_{\mathbf{3 0}}$ & $\mathbf{N}_{60}$ & $\mathbf{N}_{90}$ & $\mathbf{N}_{120}$ & Mean \\
\hline $1^{\text {st }}$ May & 8.19 & 12.04 & 14.61 & 17.01 & 17.98 & 13.97 \\
\hline $1^{\text {st }}$ June & 5.95 & 9.42 & 10.67 & 12.66 & 12.91 & 10.32 \\
\hline Mean & 7.07 & 10.73 & 12.64 & 14.83 & 15.44 & \\
\hline & $\begin{array}{c}\text { Dates of } \\
\text { transplanting }\end{array}$ & $\begin{array}{l}\text { Nitrogen } \\
\text { levels }\end{array}$ & & & & C.D N x D \\
\hline C.D(p<0.05) & 0.30 & 0.47 & & & & 0.66 \\
\hline
\end{tabular}




\section{Int.J.Curr.Microbiol.App.Sci (2018) 7(4): 1284-1291}

Table.3 Effect of dates of transplanting and nitrogen levels on yield attributes yield of sweet corn

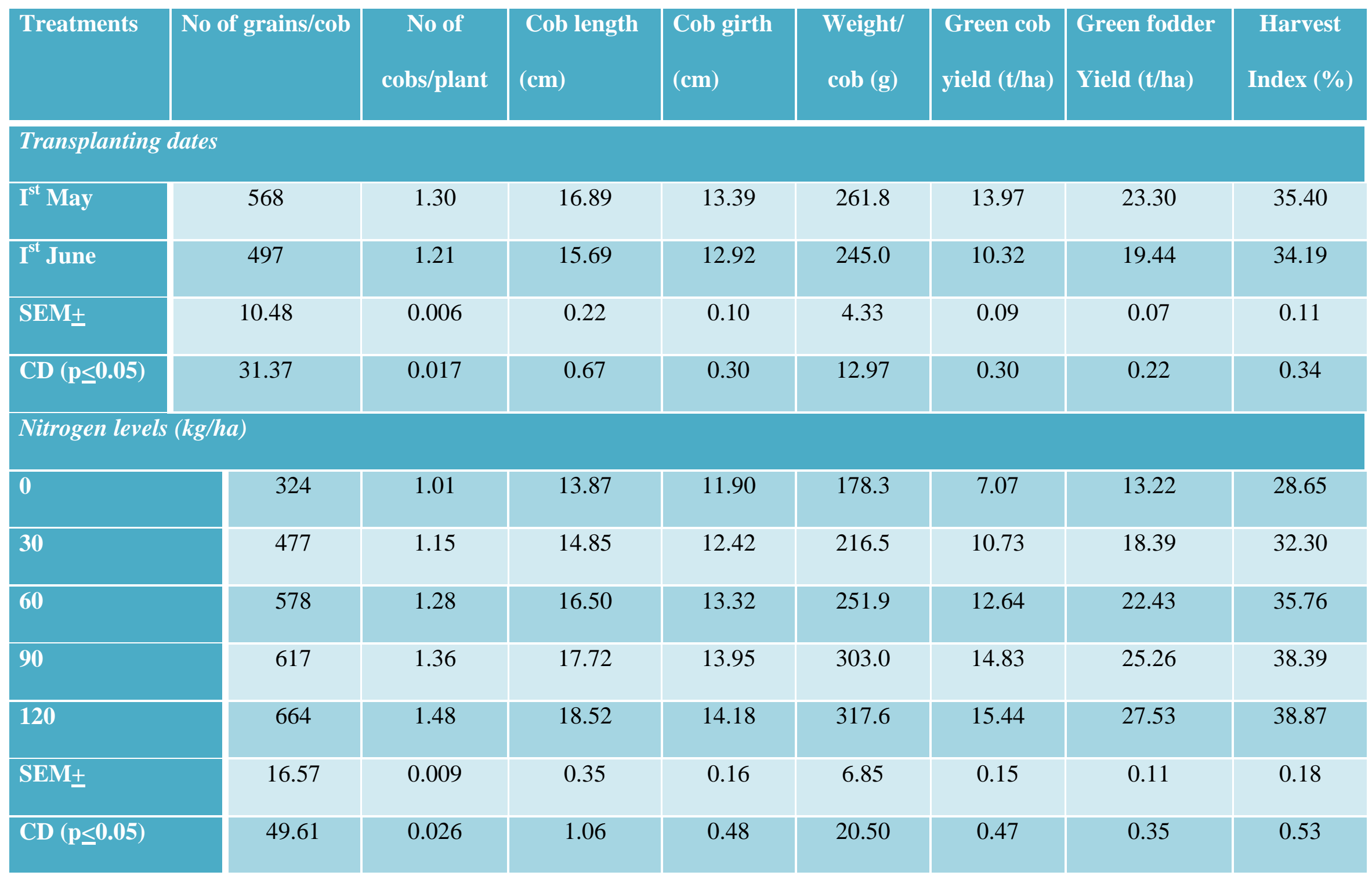


Fig.1 Effect of dates of transplanting and nitrogen on cob yield t/ha (without husk) of sweet corn

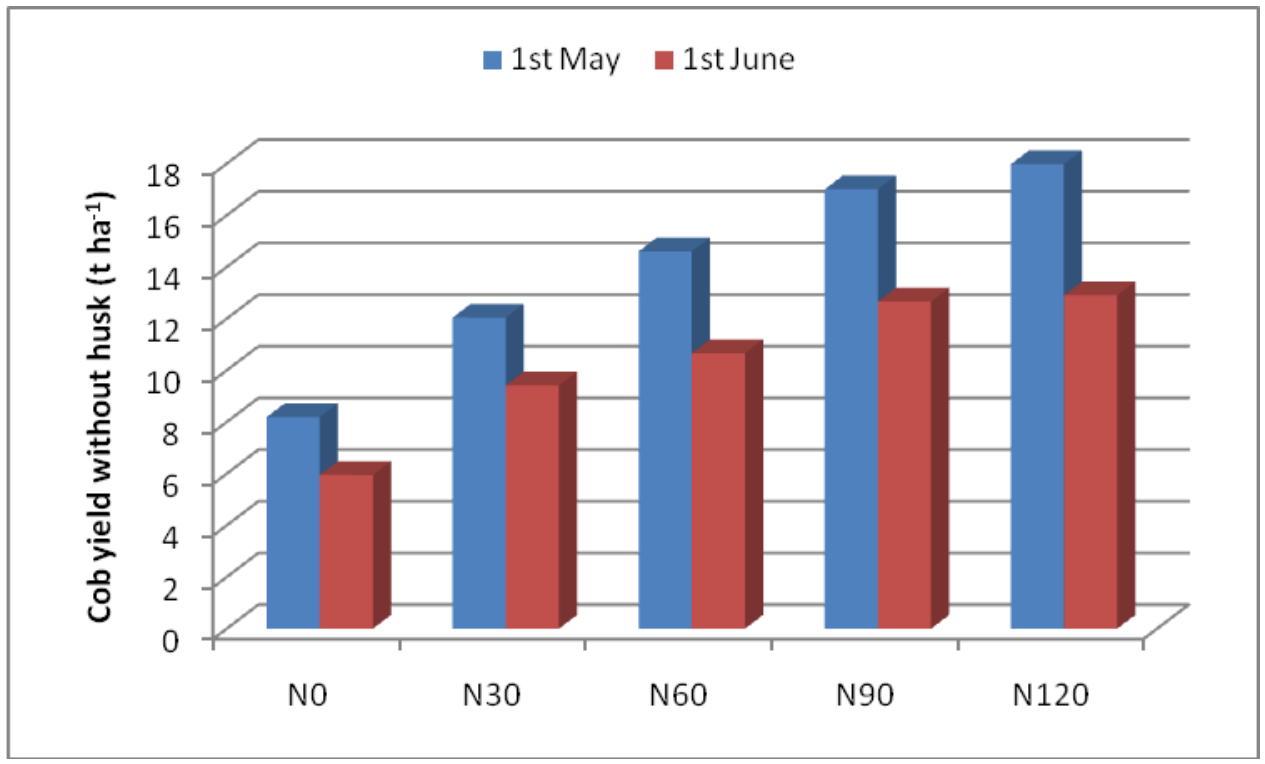

Fig.2 Relationship of sweet corn yield and N levels

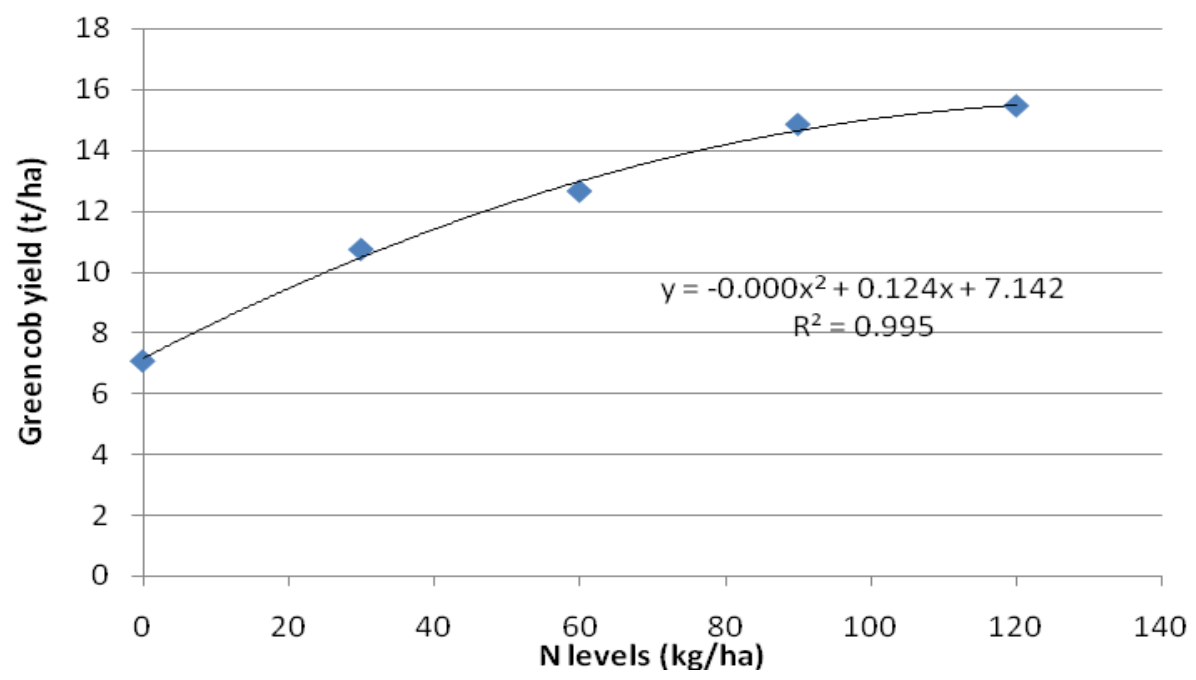

The green cob yield increased by $34 \%, 44 \%$, $52 \%$, and $54 \%$ respectively at $30,60,90$ and $120 \mathrm{~kg} / \mathrm{ha} \mathrm{N}$ over control (Table 3). The data presented in Table 4 also shows that the interaction of dates of transplanting and $\mathrm{N}$ levels with regard to green cob yield was significant. The increase in green cob yield with increase in $\mathrm{N}$ levels was significant up to 120 $\mathrm{kg} \mathrm{N} / \mathrm{ha}$ in $1^{\text {st }}$ May transplanting whereas the yield increased significantly only up to $90 \mathrm{~kg}$ $\mathrm{N} /$ ha in $1^{\text {st }}$ June transplanting. A yield of 17.98 t/ha was obtained at $120 \mathrm{~kg} \mathrm{~N} / \mathrm{ha}$ in $1^{\text {st }}$ May transplanting whereas, the yield obtained with $120 \mathrm{~N} \mathrm{~kg} / \mathrm{ha}$ in $1^{\text {st }}$ June transplanting was only $12.91 \mathrm{t} / \mathrm{ha}$ which was at par with $90 \mathrm{~kg} \mathrm{~N} / \mathrm{ha}$ (12.66 t/ha). Thus $1^{\text {st }}$ May transplanting showed higher response to $\mathrm{N}$ than $1^{\text {st }}$ June transplanting (Fig. 1). Delayed transplanting of sweet corn resulted in a significant decline in the yield contributing components i.e. cob length, cob weight, cob girth, number of cobs per plant and number of grains per cob etc. This might be due 
to reduction in growth period, higher temperature which increased the respiration rate of plant resulted in reduced net photosynthates, decreased translocation rate of photosynthates from source to sink. Khan et al., (2002), Williams, (2008) and Namakka et al., (2008) reported similar results. On the other hand the earlier sown crop was exposed to better growing conditions that resulted in higher biomass production and yield.

The results indicated that application of higher $\mathrm{N}$ doses significantly increased cob length, cob diameter, weight of cob with and without husk, number of cobs/plant, grains/cob and number of rows/cob. The increased availability of photosynthates might have enhanced number of flowers and their fertilization resulting in higher number of filled cobs and grains/cob.

\section{Optimum economic dose and relative economics}

The economically optimum dose has been estimated through production functions by the procedure discussed in detail in the materials and methods Thus, economically optimum $\mathrm{N}$ dose calculated was $132 \mathrm{~kg} / \mathrm{ha}$ i.e., increasing the fertilizer dose of $\mathrm{N}$ even upto $132 \mathrm{~kg} / \mathrm{ha}$ is economically viable for the farmer and will result in higher returns (Fig. 2). In present investigation it was observed that early sowing on $1^{\text {st }}$ May with $120 \mathrm{~kg} / \mathrm{N}$ ha recorded higher net profit and benefit cost ratio of ₹ 696423 and 8.5 , respectively. The reason was higher number of cobs and green fodder yield in this treatment combination than others without any addition in cost of cultivation. These results are in accordance with the findings of, Sharma et al., (2000), Mokhtarpour et al., (2005), Suthar et al., (2014) and Chouhan et al., (2015).

From this study it was concluded that $1^{\text {st }}$ May transplanting was superior in producing higher sweet corn and green fodder yield. Among the $\mathrm{N}$ levels, $120 \mathrm{~kg} / \mathrm{ha}$ produced significantly higher sweet corn and fodder yield for $1^{\text {st }}$ May transplanting.

\section{References}

Abdulbaki, A.A., and Anderson, J.D. 1973. Vigour determination in soybean seed by multiple criteria. Crop Sci. 13: 630-633

Anapalli, S.S., Ma, L., Nielsen, D.C., Vigil, M.F. and Ahuja, L.R. 2005. Simulating planting date effects on corn production using RZWQM and CERES-Maize models. Agronomy Journal 97: 58-71.

Bindhani, A., Barik, K.C., Garnayak, L.M. and Mahapatra, P.K. 2008. Productivity and nitrogen use efficiency of baby corn (Zea mays L.) at different levels and timing of nitrogen application under rainfed conditions. Indian Journal of Agricultural Sciences 78: 629-631.

Bockstaller, C. and Girardin, P. 1994. Effect of seed size on maize growth from emergence to silking. Maydica 39: 213218.

Bunting, E. S. 1971. Plant density and yield of shoot dry material in maize in England. Journal of Agricultural Science 77: 175185.

Chouhan, B.S., Vjadhav, K., Singh, B., Singh, S. and Kunwar, P. 2015. Performance of Sweet corn under varying fertility levels in summer season. Annals of Agricultural Research p. 167.

Cirilo, A.G. and Andrade, F.H. 1996. Sowing date and maize productivity: I. Crop growth and dry matter partitioning. Crop Science 34: 1039-1043.

Havlin, J.L., Beaton, J.D., Tisdale, S.L. and Nelson, W. L. 2005. Soil fertility and fertilizers: An introduction to nutrient management (5). Upper Saddle River, NJ: Pearson Prentice Hall.

Idikut, L. 2013. The effects of light, temperature and salinity on seed germination of three maize forms. Greener Journal of Agriculture Science 3: 246-253.

Inglett, G. E. 1970. Corn culture, processing and products. AVI Publishing corporation, London, England p. 360. 
Khan, N., Qasim, M., Ahmed, F., Naz, F. and Khan, R. 2002. Effect of sowing dates on yield of maize under agroclimatic conditions of Kaghan valley. Asian Journal of Plant Sciences 1: 146-147.

Lauer, J.G., Carter, P.R., Wood, T.M., Diezel, G., Wiersma, D.W., Rand, R. E. and Mlynarek, M. J.1997. Corn hybrid response to planting date in the northern Corn Belt. Agronomy Journal 91(5): 834839.

Mokhtarpour, H., Mosavat, S. A., Bazi, M. and Saberi, A. 2005. Effects of sowing date and plant density on ear yield of sweet corn (Zea mays L. varsaccharata) KSC403su. Iranian Journal of Crop Sciences 8: 171-183.

Moosavi, S.G., Seghatoleslami, M.J. and Moazeni, A. 2012. Effect of planting date and plant density on morphological traits, LAI and forage corn yield. International Research Journal of Applied and Basic Science 3(1): 57-63.

Mullins, C.A., Straw, R.A., Pitt, B.D. Jr., Onks, D.O., Mullen, M.D., Reynalds, J. and Kirchner, M. 1999. Response of selected sweet corn cultivars to nitrogen fertilization. Horticultural Technology 9: 32-35.

Namakka, A., Abubakar, I.U., Sadik, I.A., Sharifia, A.I. and Hassan, A.H. 2008. Effect of sowing dates and nitrogen level on the yield and yield components of two extra early maize varieties in Sudan Savanna of Nigeria. Asian Research Publishing Network Journal of Agriculture and Biological Science 3(2): $1-5$.

Paradar, V.K. 2005. Development of integrated nutrient management system through organic sources to enhance productivity of maize based cropping under rainfed ecosystem at Chhindwara. $48^{\text {th }}$ Annual Progress Report, All India Coordinated Maize Improvement Project, Directorate of Maize Research, Pusa Campus, New Delhi p. 77.

Peterson, J. M., Perdomo, J. A. and Burris, J. S. 1995. Influence of kernel position, mechanical damage and controlled deterioration on estimates of hybrid maize seed quality. Seed Science Technology 23: 647-657.

Ramankutty, N., Foley, J.A., Norman, J.A. and McSweeney, J.A. 2002. The global distribution of cultivable lands: Current patterns and sensitivity to possible climate change. Global Ecology Biogeography 11: 377-392.

Sharma, S.K., Thakur, R.C. and Rana, R.S. 2000. Production potential of maize based cropping system under rainfed conditions. Agricultural Sciences Digest 20(3): 187188.

Suthar, M., Singh, D., Nepalia, V. and Singh, A. K. 2014. Performance of sweet corn (Zea mays) varieties under varying fertility levels. Indian Journal of Agronomy 59(1): 168-170.

Varga, P., Berzy, T., Anda, A. and Ertsey, K. 2012. Relationship between seed harvesting method and seed physiological quality for a number of pioneer maize hybrids. Maydica 57: 220-225.

Williams, M. M.2008. Sweet corn growth and yield responses to planting dates of the north central United States. Horticulture Science 43: 1775-1779.

\section{How to cite this article:}

Abrar A. Khan, Ashaq Hussain, Manzoor, A. Ganai, Zahida Rashid and Zahoor A. Dar. 2018. Response of Sweet Corn Hybrid to Transplanting Dates and Nitrogen Levels under Temperate Conditions. Int.J.Curr.Microbiol.App.Sci. 7(04): 1284-1291. doi: https://doi.org/10.20546/ijcmas.2018.704.143 